Sains Malaysiana 50(8)(2021): 2433-2444

http://doi.org/10.17576/jsm-2021-5008-24

\title{
Physical Properties of Newly Developed Resin Modified Glass Ionomer Cement with Synthesised Coumarin Derivatives
}

(Sifat Fizikal Pembentukan Simen Ionomer Kaca Resin Terubahsuai Baharu bersama Sintesis Terbitan Kumarin)

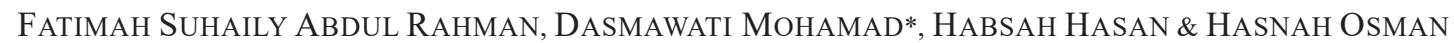

\begin{abstract}
The aim of this study was to determine the effects of two types of coumarin derivatives, namely, 3-acetylcoumarin $(A C)$ and coumarin thiosemicarbazone (CT) on surface characteristics such as the roughness, hardness, and morphology of resin-modified glass-ionomer cement (RMGIC). The release of coumarin from the fabricated RMGIC was also investigated. AC and CT at 1.0\% (w/w) concentration were added into $0.3 \mathrm{~g}$ of RMGIC powder and mixed with 0.1 $g$ of polyacrylic acid. The fabricated RMGIC-AC and RMGIC-CT were evaluated for surface characteristics such as roughness, hardness and topography. The coumarin release of AC and CT from RMGIC was also determined. The RMGIC-CT demonstrated a decreased roughness value among the materials. The surface roughness exhibited by the RMGIC was statistically higher $(p<0.05)$ than that of fabricated materials. The RMGIC-AC was observed to have the highest hardness value compared to the RMGIC-CT and RMGIC, and this value was significantly higher $(p<0.05)$. The surface morphologies of the RMGIC-AC and RMGIC-CT showed a number of pores and irregular surfaces. Meanwhile, the surface roughness value of the RMGIC was statistically higher $(p<0.05)$ than both RMGIC-AC and RMGIC-CT. In conclusion, the large-sized AC particles significantly increased the surface hardness of the fabricated RMGIC. Conversely, the particle size of both coumarins were not influenced the surface roughness value and the coumarin release profile of fabricated RMGICs.
\end{abstract}

Keywords: Coumarin; glass ionomer cement; hardness; microstructure; roughness

\section{ABSTRAK}

Tujuan kajian ini dijalankan adalah untuk mengenal pasti kesan dua jenis terbitan kumarin, iaitu 3-asetilkumarin (AC) dan kumarin thiosemikarbazon (CT) ke atas pencirian permukaan simen ionomer kaca resin terubah suai (RMGIC) seperti sifat kekasaran, kekerasan dan morfologi. Pembebasan kumarin daripada RMGIC difabrik turut dikaji. AC dan CT dengan kepekatan 1.0\% $(w / w)$ ditambah kepada $0.3 \mathrm{~g}$ serbuk RMGIC dan kemudiannya dicampurkan dengan 0.1 $g$ asid poliakrilik. RMGIC-AC dan RMGIC-CT difabrik dinilai bagi pencirian permukaan seperti kekasaran, kekerasan dan topografi. Pembebasan kumarin AC dan CT daripada RMGIC juga dinilai. RMGIC-CT menunjukkan penurunan nilai kekasaran berbanding bahan-bahan yang lain. Kekasaran permukaan yang ditunjukkan RMGIC adalah tinggi secara statistik $(p<0.05)$ berbanding bahan-bahan difabrik. RMGIC-AC menunjukkan nilai kekerasan yang paling tinggi berbanding RMGIC-CT dan RMGIC, dan ia tinggi secara signifikan $(p<0.05)$. Morfologi permukaan pada RMGIC-AC dan RMGIC-CT memperlihatkan beberapa lompang dan permukaan tidak sekata. Sementara itu, nilai kekasaran pada RMGIC adalah tinggi secara statistik $(p<0.05)$ berbanding RMGIC-AC dan RMGIC-CT. Kesimpulannya, zarah bersaiz besar AC meningkatkan kekerasan secara statistik pada RMGIC difabrik. Sebaliknya, saiz zarah kedua-dua kumarin tidak mempengaruhi nilai kekasaran permukaan dan profil pembebasan kumarin pada RMGIC difabrik.

Kata kunci: Kekasaran; kekerasan; kumarin; mikrostruktur; simen ionomer kaca 


\section{INTRODUCTION}

There are many types of tooth coloured restorative materials in the market nowadays which includes resin modified glass ionomer cement (RMGIC). It is a waterbased cement with hybrid composition of conventional glass ionomers and 2-hydroxyethylmethacrylate (HEMA) resin monomer (Berzins et al. 2010). RMGIC has various applications similar to that conventional glass ionomer cement (GIC) in restorative dentistry, such as for the lining underneath other restorative materials, as a luting agent, and for core build-up and restoration (Sidhu 2011). There are several advantages possessed by RMGIC such as excellent biological properties, chemically bonded to the enamel, and has a coefficient of thermal expansion that is close to that of tooth structures (Pinto-Sinai et al. 2018). In addition, RMGIC had shown an improvement in mechanical properties, reduce its setting time, and attenuate its sensitivity to moisture compared to conventional GIC (Beltagy \& Elhatery 2018). Nevertheless, both RMGIC and conventional GIC shared a unique property of fluoride releasing materials due to their fluoroaluminasilicate content.

Though fluoride ions of RMGIC can act as antibacterial agent but the insufficient of fluoride release may be the reason for the low antibacterial activity in the material (Tüzüner \& Ulusu 2012). The incorporation of various antibacterial compounds into RMGIC has been studied extensively in order to increase the antibacterial activity, thus, reduce the chances of secondary caries (Chen et al. 2018). Chlorhexidine has been introduced since 1950's and has been considered as one of the most effective antimicrobial agents on dental microorganisms (Balagopal \& Arjunkumar 2013). Studies have suggested due to its potential, incorporation of chlorhexidine was significantly used in RMGIC, improved their inhibitory action on residual microorganism and would reduce the potential of secondary caries (Sanders et al. 2002; Türkün et al. 2008). However, some findings showed that application chlorhexidine in RMGIC caused a decrease in the physical properties of the material (Tüzüner \& Ulusu 2012). In successful performance of restorative material, physical properties play a significant role. Rougher surface of a restorative material will allow for more accumulation of microorganisms, and smoother surface of the material will give an aesthetic effect compared to rough surface that will give a dull look (Rashid 2014). Meanwhile, high surface hardness is an important factor in controlling wear resistance, hence can be an indication of the material durability (Savabi et al. 2013).

Recently, many studies have shown that some coumarin derivatives have antibacterial properties that reduce bacterial growth by inhibiting the key enzyme in the biosynthesis pathway of fatty acids (Hu et al. 2018; Puttaraju et al. 2013). Coumarin (2H-1-benzopyran-2one), as a parent compound is firstly isolated from plant tonka bean (fruits of Dipteryx odorata), and it composed by fused benzene and $\alpha$-pyrone rings (Rohini \& Srikumar 2014). Though coumarin has potential in antimicrobial activity, but coumarin derivatives exerted stronger activity than coumarin. Despite of naturally extracted, coumarin derivatives can also be produced synthetically with various mechanisms of reactions. In this study, Knoevanagel condensation technique was used to synthesis 3-acetylcoumarin (AC) due to its simple method, high yield and short reaction times (Stefanachi et al. 2018). Meanwhile, preparation of coumarin thiosemicarbazone (CT) through Schiff base reaction is due to the existence of azomethine group which demonstrated a good bioactivity (Da Silva et al. 2011). The cytotoxicity activity of $\mathrm{AC}$ and $\mathrm{CT}$ has been investigated previously and the finding showed no cytotoxicity effect on human periodontal ligament fibroblast (HPdLF) cell line (Rahman et al. 2016).

Azlisham et al. $(2017,2015)$ had incorporated coumarins in RMGIC and the result of their flexural and compressive strength shown promising finding. The newly-developed RMGIC with coumarin derivatives is presumed to have good antibacterial properties that do not jeopardize its physical properties. Therefore, this study was aimed to evaluate the surface topography, hardness and coumarin release of fabricated RMGIC.

\section{MATERIALS AND METHODS}

\section{MATERIAL FABRICATION}

The coumarin derivatives, namely, 3-acetylcoumarin (AC) and coumarin thiosemicarbazone (CT), were synthesised according to the previous study (Rahman et al. 2016). The synthesis of AC and CT were carried out using Knoevanagel condensation and Schiff base reaction as shown in Figure 1. The chemical elucidation of AC and CT also has been published by Rahman et al. (2016). The morphological structure and particle size of AC and CT 
were evaluated under field emission scanning electron microscopy (FESEM).

In this study, RMGIC (Fuji II, LC, GC Corporation, Japan) was used. According to the manufacturer, the application of this material is suggested for restoration, core build-up, and as a base or liner. The newlydeveloped RMGIC incorporated coumarin derivatives was prepared according to the powder to liquid ratio recommended by the manufacturer, with the addition of $1 \%$ of the coumarin type in each composition. First, approximately $0.3 \mathrm{~g}$ of RMGIC powder was weighed, and $1.0 \%(\mathrm{w} / \mathrm{w})$ of $\mathrm{AC}$ was mixed with the cement powder.
The powders were mixed homogeneously in a mortar. Approximately $0.1 \mathrm{~g}$ of polyacrylic acid was added and blended together. The fabricated material was named RMGIC-AC. Similarly, the same procedure was followed for the $\mathrm{CT}$, and the fabricated material was named RMGIC-CT. For the control, RMGIC was prepared without the coumarin. These materials were packed in acrylic moulds $(5 \times 2 \mathrm{~mm})$ in triplicate for each group, and covered with a mylar strip. The sample material was pressed with a microscopic glass slide to obtain a flat surface. Next, it was photo-polymerized for $40 \mathrm{~s}$ with a light cure (EliparTM Freelight 2 LED, 3M ESPE) at a light intensity of $1000 \mathrm{~mW} / \mathrm{cm} 2$ at a distance of approximately $2 \mathrm{~mm}$.

a)

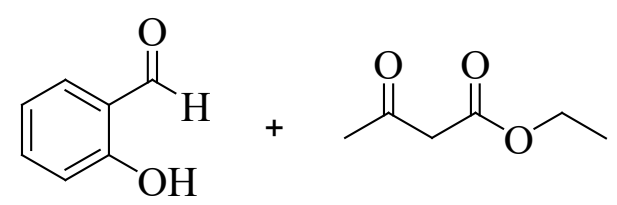

Salicylaldehyde Ethyl acetoacetate<smiles>CC(=O)c1cc2ccccc2oc1=O</smiles>

3-acetylcoumarin (AC)

b)<smiles>CC(=O)c1cc2ccccc2oc1=O</smiles>

3-acetylcoumarin (AC)<smiles>[R]OC(=O)C(=O)O</smiles>

Thiosemicarbazide

Coumarin thiosemicarbazone (CT)

FIGURE 1. Schematic reaction of a) AC and b) CT

FOURIER TRANSFORM INFRARED (FTIR)

FTIR-ATR, model Tensor 27 IR Spectrometer from Bruker (US) was used to identify the functional groups of the RMGIC, RMGIC-AC and RMGIC-CT. The spectra were analysed in the range of $600-2000 \mathrm{~cm}^{-1}$.

\section{SURFACE ROUGHNESS}

The surface roughness of the fabricated RMGICs and control $(n=6)$ was performed by a two-dimensional surface profilometer (Surfcom FLEX-50A, Accretech, Japan). The cut off value, evaluation length and measure speed were 
set at $0.8 \mathrm{~mm}, 4 \mathrm{~mm}$, and $0.15 \mathrm{~mm} / \mathrm{s}$, respectively. The parameter of roughness was recorded as arithmetic mean of the sum of roughness profile value, $\mathrm{Ra}$.

\section{SURFACE HARDNESS}

The evaluation of the surface hardness of the fabricated RMGICs and the control was carried out using a Vickers diamond indenter under a load of $1 \mathrm{~kg}$ for $10 \mathrm{~s}$ (Vickers Hardness Tester, Model VM 50, India). Three spots were selected randomly and analysed for each material. The mean value of the three indentations on six samples $(n=6)$ per group was calculated and the hardness value (HV) was recorded.

\section{SCANNING ELECTRON MICROSCOPY (SEM)}

The morphological observation of the RMGIC and fabricated RMGICs was performed by immersion in artificial saliva at different intervals of 1, 7, and 14 days. All the materials were compared with the control group at day 0 . The tested materials were mounted on the SEM specimen stubs and coated with a thin layer of gold using an ion sputtering device (Leica EM SCD 005, Republic Czech) before the viewing process. The morphological observation was carried out at a magnification of between $250 \times$ and $20,000 \times$ with and SEM accelerating voltage of $5 \mathrm{kV}$ (Quanta $450 \mathrm{FEG}$, Fei, Netherlands). ImageJ software was operated to estimate the pores distribution of the materials.

\section{COUMARIN RELEASE STUDY}

The standard solutions of coumarins in dimethylsulfoxide (DMSO) were first prepared in serial dilutions in the range of 0.2-1.2 mM. The absorbance of the serial dilutions was determined by a UV spectrophotometer. Four points calibration curve was obtained which resulting the absorbance coefficient, $\varepsilon$. The wavelength of AC and CT was recorded at $290 \mathrm{~nm}$ and CT at $350 \mathrm{~nm}$, respectively. The concentration of coumarin release was calculated prior to calibration curve of AC and $\mathrm{CT}$ in which the value of $\mathrm{m}$ (slope of calibration curve) was considered as absorbance coefficient, $\varepsilon$. The concentration of coumarin release of fabricated AC and CT with RMGIC were analysed based on Beer-Lambert law as follows:

$$
\mathrm{A}=\varepsilon b c
$$

where A is the absorbance; $\mathrm{b}$ is the path length; $\mathrm{c}$ is the concentration; and $\varepsilon$ is the absorbance coefficient.

The fabricated RMGIC with AC and CT were immersed in $2 \mathrm{~mL}$ of artificial saliva (Pharmacy Department, HUSM) for 30 days, with the solution being replaced daily. The materials were incubated in a shaking water bath (Julabo, Germany) at $37^{\circ} \mathrm{C}$ and a speed of 121 rpm. $1 \mathrm{~mL}$ of the collected solution was inserted into a 96well plate and recorded by micro plate readers at $290 \mathrm{~nm}$ (AC) and $350 \mathrm{~nm}(\mathrm{CT})$. The released concentrations (ppm) were plotted against time.

\section{STATISTICAL ANALYSIS}

The results of the hardness of the different types of RMGICs was analysed by an analysis of variance (ANOVA) using the IBM SPSS software version 24.0 (Chicago, IL, USA). A Tukey post-hoc test was carried out to assess the normality of the population. The difference between the mean values for each group was considered to be statistically different when $p<0.05$. Meanwhile, the result of coumarin release study was not normally distributed, thus nonparametric statistical tests were employed. The data was analysed using the Mann-Whitney U-test and subjected to two-independent sample tests.

\section{RESULTS AND DISCUSSION}

\section{FTIR ANALYSIS AND POSSIBLE REACTION BETWEEN} RMGIC AND COUMARIN DERIVATIVES

In this study, the functional group of the fabricated RMGIC with coumarins was elucidated by FTIR, as shown in Figure 2. The spectrum of each RMGIC-AC and RMGIC-CT showed a pattern that was similar to that of the RMGIC.

The moiety of the coumarins was not clearly observed in the spectrum as both compounds exhibited similar functional groups, namely, carbonyl $(\mathrm{C}=\mathrm{O}), \mathrm{C}-\mathrm{H}$ and $\mathrm{C}-\mathrm{O}$, which presumably overlapped with each other. However, the $\mathrm{C}=\mathrm{O}$ peaks of the fabricated RMGIC-AC and RMGIC-CT were clearly shown at absorbance of 1712 and $1724 \mathrm{~cm}^{-1}$, respectively, and were slightly shifted than the peak of the RMGIC at $1700 \mathrm{~cm}^{-1}$. This finding postulated that during the mixing of the coumarins with the RMGIC, the nucleophile of the COO- from the polyacrylic acid probably attacked any possible electrophilic ions, 
including the carbonyl group of the coumarin substrate, as shown in Figure 3. The carbonyl group in these coumarins would provide a strong electron-attracting force, which enhanced the reactivity of the adjacent double bond function and introduced the nucleophilic addition at the centre, thus, giving a chance for an interaction to occur between the polyacrylic acid in the RMGIC and the coumarins (Salem et al. 2016). However, the functional group of $\mathrm{C}=\mathrm{S}$ at absorbance of $1240 \mathrm{~cm}^{-1}$ for CT was not clearly seen in the spectra of fabricated RMGIC-CT (Figure 2). The other possible reaction site of carboxylate group of RMGIC and coumarins also can be postulated at amine group of CT and the final structure of the fabricated materials can be predicted as shown in Figure 4. Nevertheless, to further confirm the bonding of the structure of the fabricated materials, a solid-state nuclear magnetic resonance (NMR) is suggested for future evaluation.

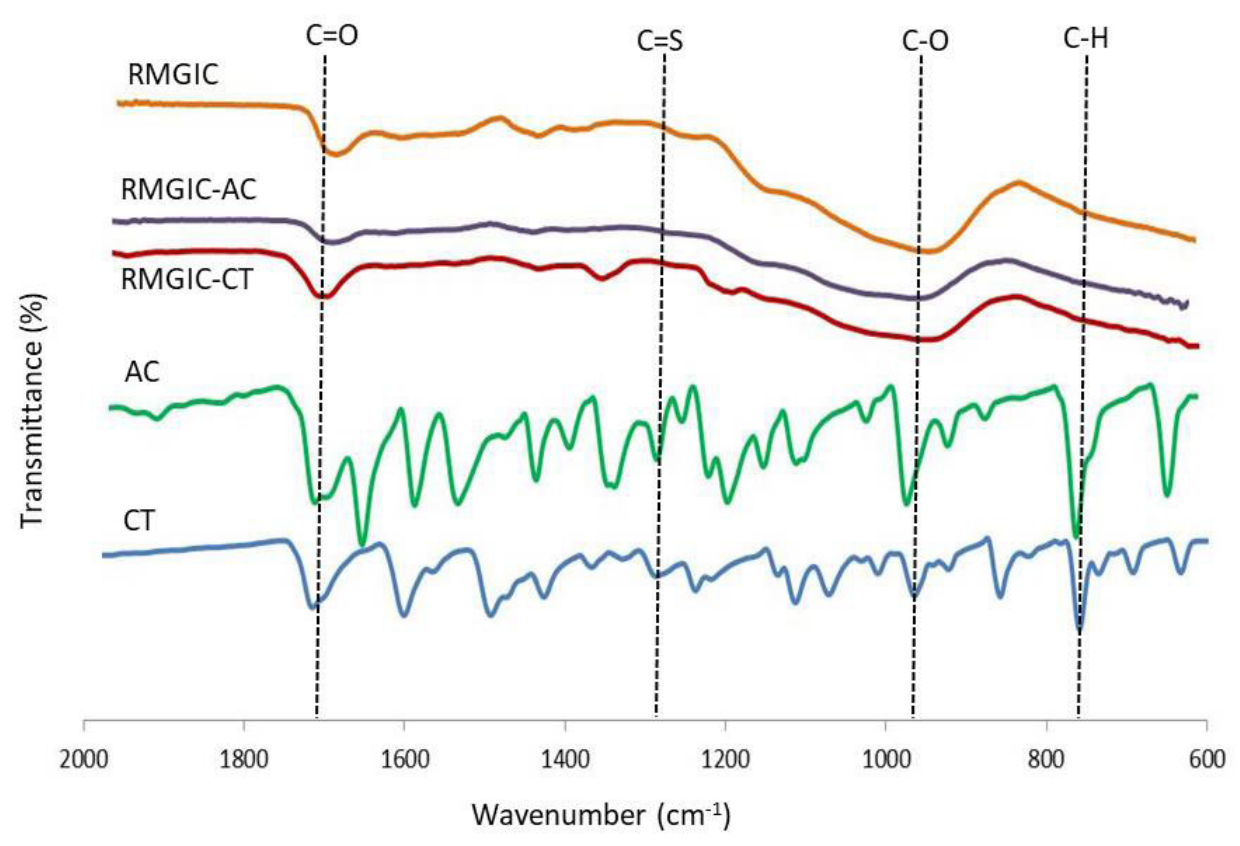

FIGURE 2. FTIR spectra of RMGIC, RMGIC-AC, RMGIC-CT and coumarins ( $\mathrm{AC}$ and $\mathrm{CT}$ )

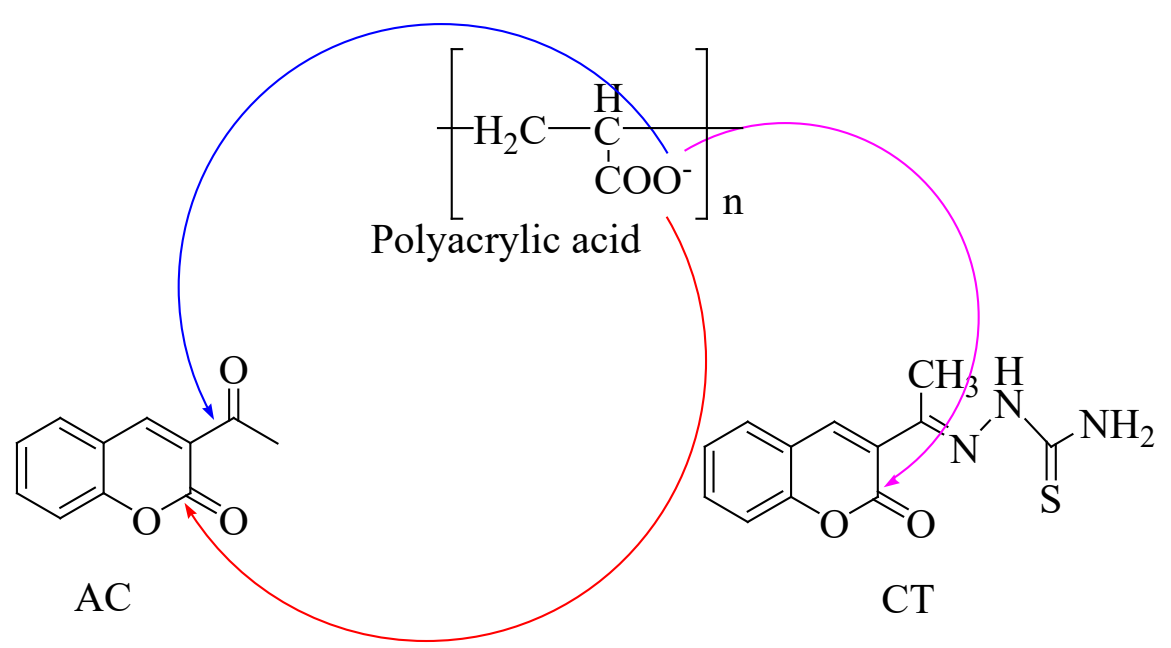

FIGURE 3. Possible sites of nucleophilic attack on AC and CT at carbonyl groups 


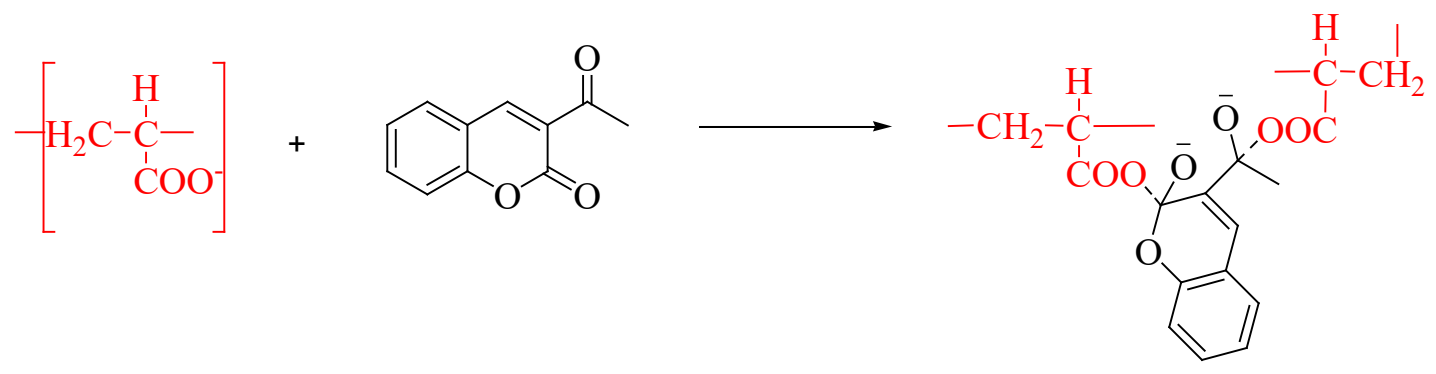

Polyacrylic acid<smiles>CCCC(C)CC(=O)[O-]</smiles>

Polyacrylic acid
$\mathrm{AC}$<smiles>CC(=N)c1cc2ccccc2oc1=O</smiles>

CT
RMGIC-AC

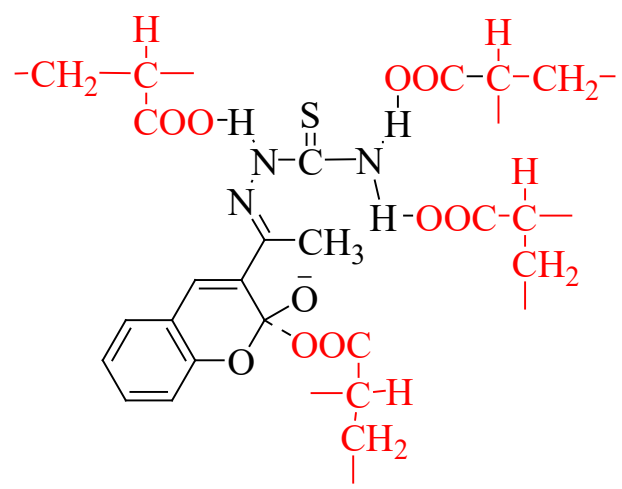

FIGURE 4. Possible sites of reaction between carboxylate (COO-) of polyacrylic acid in RMGIC and a) AC; and b) CT

\section{SURFACE ROUGHNESS OF FABRICATED RMGIC}

Table 1 shows that the surface roughness of the fabricated RMGIC with coumarins were significantly reduced in comparison with that of the RMGIC. This finding may have been due to the incorporation of the coumarins, which decreased the surface roughness of the RMGICCT $(0.28 \mu \mathrm{m})$ and RMGIC-AC $(0.33 \mu \mathrm{m})$. This finding could be due to the incorporation of $\mathrm{AC}$ and $\mathrm{CT}$ in the RMGIC that may increase the homogeneity of the mixture, thus, provided more surface interaction between the coumarins and RMGIC (Najeeb et al. 2016). Previous study reported that the reduced particle size can enhance the uniformity of mixture, thus, controlled the particle aggregation. Meanwhile, the commercial RMGIC showed the highest value of $0.93 \mu \mathrm{m}$. Different sizes of CT and AC coumarins, did not show any significant different in $\mathrm{Ra}$ values of fabricated RMGIC's. Additionally, maintaining a smooth surface of restoration would prolong the success of the treatment (Gharechahi et al. 2012). The initial formation of an oral biofilm starts with the adherence of bacteria to the conditional layer. Within this phase, bonds are created between the bacteria and the conditional layer, and these bonds may not be strong, but they will become stronger over time. Smoother surface will reduce the ability of bacteria to strongly adhere to the surface (Gharechahi et al. 2012). The bacteria will be easily removed mechanically during brushing of the surface. This will reduce a prolonged bacterial colonization and subsequently prevent biofilm formation. 
TABLE 1. Surface roughness, Ra of RMGIC and RMGIC-coumarins with standard deviations

\begin{tabular}{ll}
\hline Materials & Ra, $\mu \mathrm{m}$ \\
\hline RMGIC & $0.93(0.18)^{\mathrm{a}}$ \\
RMGIC-AC & $0.33(0.03)^{\mathrm{b}}$ \\
RMGIC-CT & $0.28(0.04)^{\mathrm{b}}$ \\
\hline
\end{tabular}

*Same superscript letters are not significantly different $(\mathrm{p}<0.05)$

\section{SURFACE HARDNESS OF FABRICATED RMGIC}

Figure 5 shows that the incorporation of $\mathrm{AC}$ in the RMGIC resulted in a significant $(\mathrm{p}<0.05)$ increase in the hardness value $(68.80 \mathrm{HV})$ as compared to the commercial RMGIC (54.53 HV) and RMGIC-CT (60.12 HV). This was because the size of the AC particles was much bigger than that of the CT particles. This finding was in agreement with the study by Kundie et al. (2018), which suggested that large-sized particles, particularly micron-sized particles, can enhance the hardness value of dental material. The addition of $1 \%$ organic compound also showed a comparable hardness with Tüzüner and Ulusu (2012). It was also suggested that hardness property is related to the molecular stability of the component in the material. This stability is depending on the chemical energy that stored in the covalent bonds holdings atoms together in the form of molecule (Gilman 2009). In the fabricated materials of RMGIC with coumarins, possibility of chemical energy that bond between carboxylate group of polyacid and cationic groups of AC is higher than CT. This postulation may due to the bulk structure of CT that can lead to the higher steric effect than AC during the interaction with polyacid of RMGIC and eventually caused steric hindrance (Yamazaki et al. 2019). The phenomenon would dictate the reactivity of RMGIC-CT and may reduce the stability of the material, simultaneously reduced the hardness property of the material (Yamazaki et al. 2019).

Fabricated RMGIC-coumarins can potentially be used for restoration treatment, and therefore, the hardness property is important due to its resistance to an occlusal load (Tüzüner \& Ulusu 2012). The surface hardness of any restorative material should ideally be comparable with the hardness of enamel to avoid several difficulties, including multidirectional stresses and to withstand multimillion chewing cycles. A reduction in the hardness of either enamel or a restorative material may be due to the increased porosity of the material and is possibly linked to restoration failure (Akkus et al. 2017). As reported previously, commercial GIC has a lower hardness value (34 $\pm 0.05 \mathrm{HV})$ than enamel (227-732 HV) and dentin (72$94 \mathrm{HV}$ ) at any location (Zafar 2014). This study showed that there was an increase of $26.17 \%$ and $10.25 \%$ in the hardness values of both RMGIC-AC and RMGIC-CT, respectively. Hardness can also affect the occlusal wear resistance of restorative material, and a greater value may provide a good occlusal relationship between the opposing teeth, thereby reducing restoration failure (Özdemir \& Özdoğan 2018).

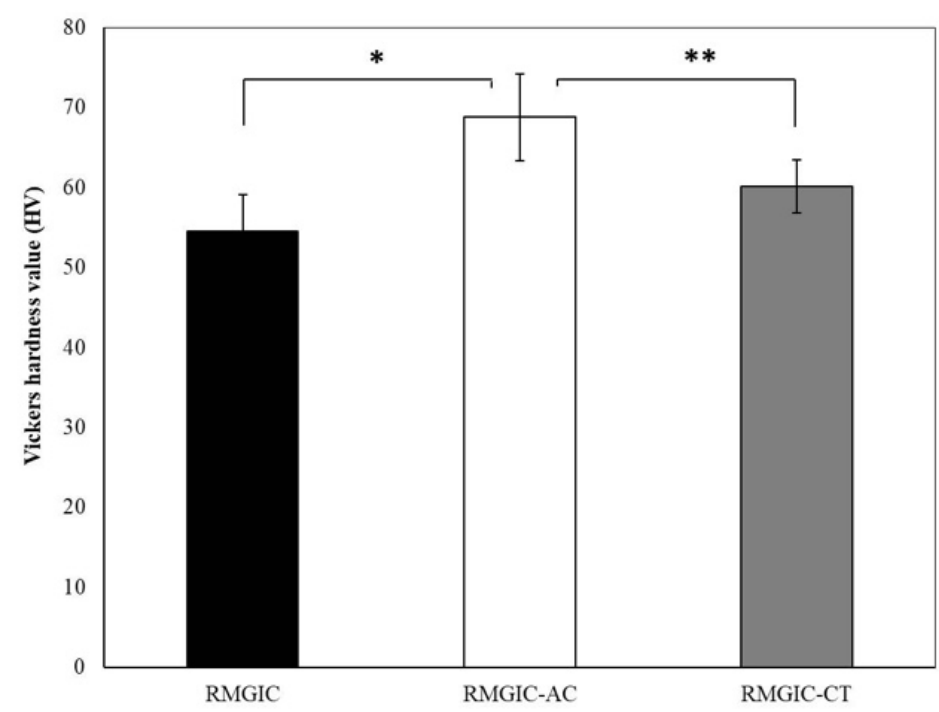

FIGURE 5. Vickers hardness value of different group; RMGIC, RMGIC-AC and RMGIC-CT. The samples are statistically different according to test ANOVA test. The significant value $(\mathrm{p}<0.05)$; between RMGIC and RMGICAC marked as *, and between RMGIC-AC and RMGIC-CT marked as ** 


\section{SEM OBSERVATION OF FABRICATED RMGIC}

The morphological characteristic of $\mathrm{AC}$ and $\mathrm{CT}$ indicated the flaky structure for both particle, but in different particle sizes as shown in Figure 6. The sizes of the $\mathrm{AC}$ and $\mathrm{CT}$ particles were found to be approximately 53.8 and $4.7 \mu \mathrm{m}$, respectively.

The morphological results showed that the commercial RMGIC experienced several changes throughout the immersion period. At day 0 , the control RMGIC was observed to have several pores on its surface (Figure 7(a)). Then, more pores and pores with a large volume were seen on day 1 of the immersion (Figure 7(b)). After a week, the pores kept expanding, while the small pores were maintained on the surface (Figure 7(c)). The surface of the control RMGIC at 14 days of immersion was found to be rougher than before, as some parts of the surface swelled and more pores with an enormous volume appeared (Figure 7(d)). The setting reaction of RMGIC occurred in $24 \mathrm{~h}$ and during this progress, the matrix is hydrated by water. The water molecule is strongly linked to the structure of the material during set reaction and it was occupied until it reached saturation rate (Souza et al. 2016). However, for further immersion, the silicate cement of material is capable of leaching ions in contact with water. Therefore, this phenomenon may initiate dissolution of the material from cracks and fissures probably leading to the larger volume of pores after $24 \mathrm{~h}$ immersion (Kuhn \& Wilson 1985).

Meanwhile, the surface morphologies of the fabricated RMGIC-AC at days 0 and 1 were recorded as being almost similar. Pores were found to be scattered on the surface of the material at both days (Figure 7(e)-7(f)). At day 7 of immersion, the size and depth of the pores became larger than before, and eventually a gigantic pore with a rough surface was produced inside the hole, as shown at 14 days of immersion (Figure 7(g)-7(h)).

For the fabricated RMGIC-CT at day 0, Figure 7(i) shows that a smooth area was detected and almost no pores could be observed on the surface of the material. Then, the appearance of several pores was seen on the surface on evaluation after $24 \mathrm{~h}$ (Figure 7(j)). More pores were created on the surface as the immersion was prolonged after a week (Figure 7(k)). An obvious long crack was found on evaluation after 14 days, and the crack created a big gap between the lines and formed a pore (Figure 7(1)).
Based on these findings, the pores had been in existence on the surface of the material before immersion in the artificial saliva solution. The occurrence of this scenario might have been due to the hand-mixing technique, which could have led to the trapping of air bubbles in the cement and the creation of pores (Nomoto et al. 2004).

After $24 \mathrm{~h}$ of immersion, the morphology of the tested materials seemed to show that there were more pores scattered on the surface, and this could have been due to the dissolution processes that occurred in the materials. According to the previous study, the dissolution processes take place in three stages; surface wash-off, leaching from pores and fissures, and diffusion from the bulk (Kuhn \& Wilson 1985). The RMGIC-CT was observed to have a characteristic morphology that was smoother than that of RMGIC-AC. The smaller particle size of the CT compared to the $\mathrm{AC}$ that was incorporated into the RMGIC increased the homogeneity of the mixture, thereby reducing the chances of air entrapment, which could initiate pore formation (Kaushik et al. 2014).

There was an increase in the volume and quantity of pores for all the materials after 7 days of immersion. It was assumed that the dissolution rate had increased and enlarged the available pores on the surface of the material. The dissolved leachable ions in the medium would have dispersed and diffused through the pores in the wet environment (Siegel \& Rathbone 2012).

At day 14 of the experiment, several swelling effects were found on the surface of the RMGIC, which did not appear on the fabricated RMGICs with coumarins. This phenomenon can be explained by considering the hydrophilicity of HEMA, which can lead to swelling, as can be seen in Figure 7(d) (Alomayri et al. 2014). Meanwhile, the bigger and deeper pores that were observed on the surface of the RMGIC-AC could have been due to the mechanism of controlled diffusion through the matrix (Siegel \& Rathbone 2012). However, the surface morphology of the RMGIC-CT was seen to be different from that of the other materials as a major crack was detected. The micro-crack that developed initially on the surface was able to propagate more because of the diffusion mechanism. This situation would have initiated the release of active substances in the medium, thus increasing the dissolution rate (Thomas et al. 2014). 
The estimation of pores distribution of RMGIC, RMGIC-AC, and RMGIC-CT has been carried out for day 7 and 14 via ImageJ software. The finding showed that RMGIC-CT has the lowest pores value among other materials (Table 2) and thereby showed a good combination effect of the material.

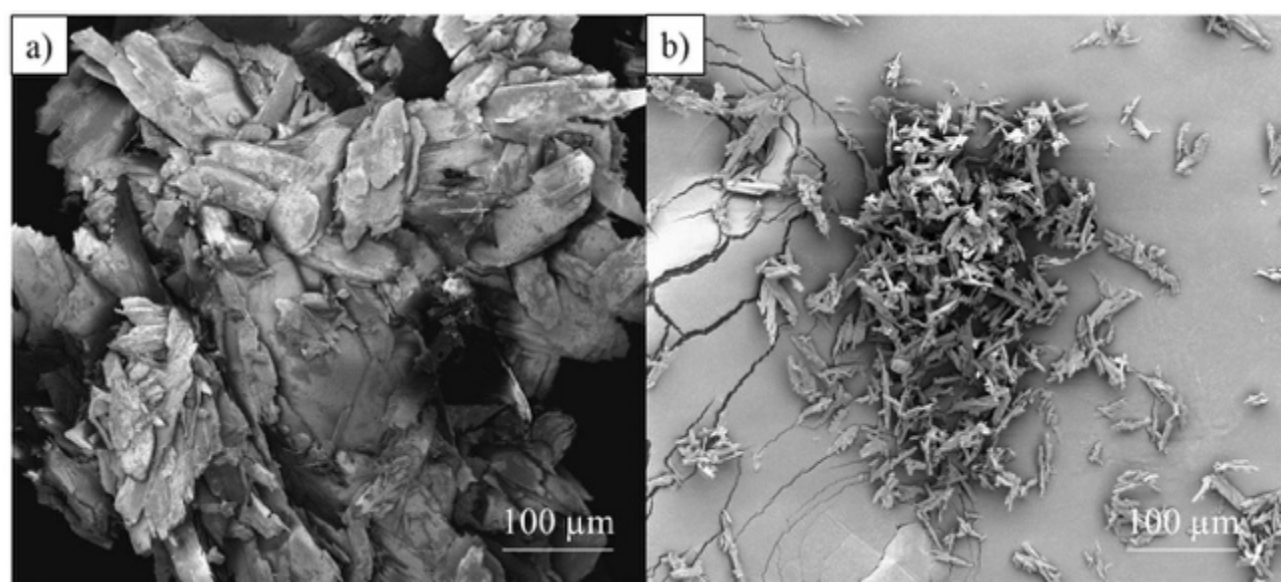

FIGURE 6. FESEM images of synthesized (a) AC and (b) CT at the magnification of $500 \times$

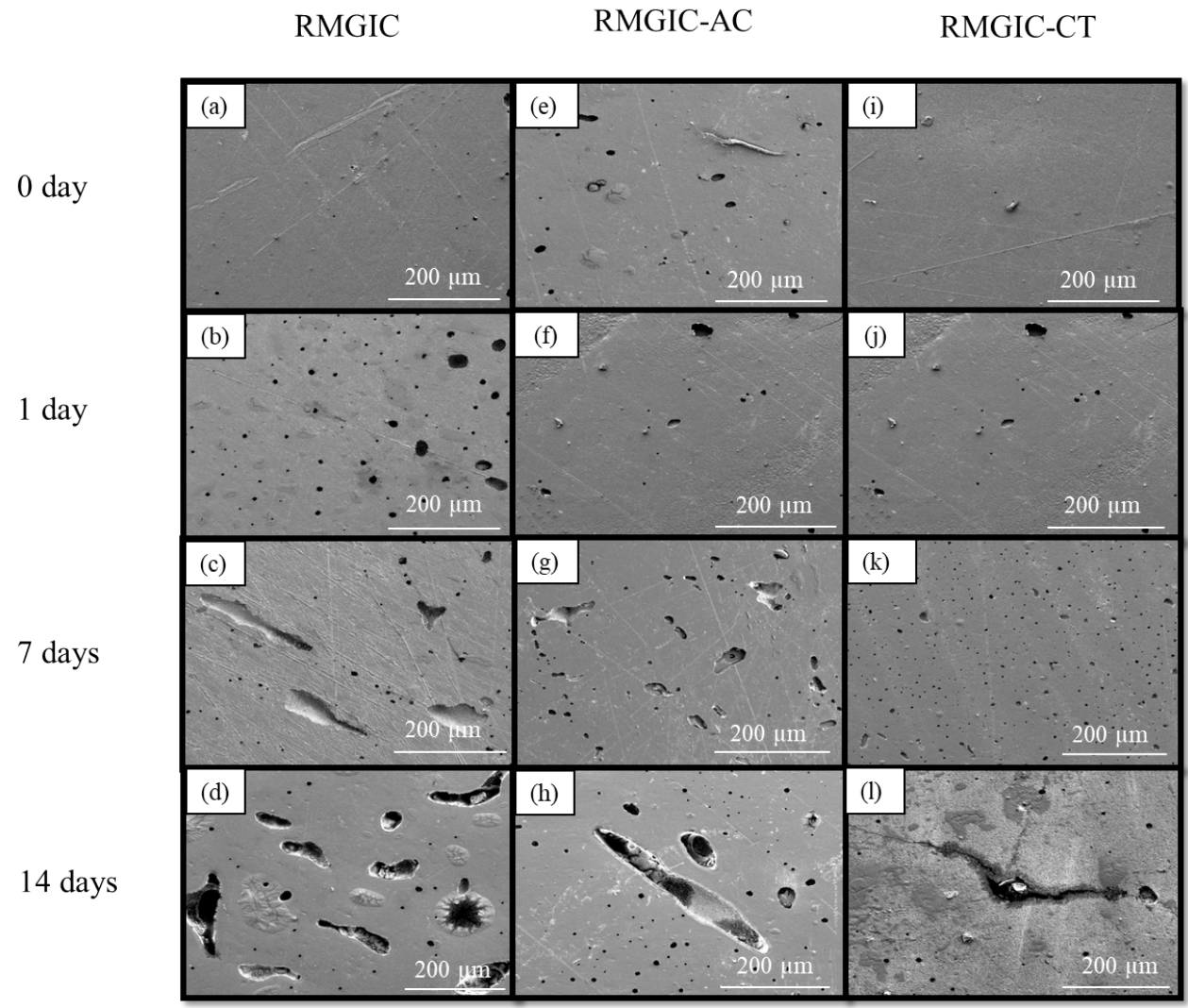

FIGURE 7. (a-1) SEM images of control RMGIC and fabricated RMGICS at day $0,1,7$ and 14 days after immersed with artificial saliva at the magnification of 500 
TABLE 2. Estimation of pores distribution of RMGIC, RMGIC-AC and RMGIC-CT after immersion in artificial saliva for 7 and 14 days via ImageJ software

\begin{tabular}{cccc}
\hline & \multicolumn{3}{c}{ Mean pores distribution of different material $(\mu \mathrm{m})$} \\
\hline Days & RMGIC & RMGIC-AC & RMGIC-CT \\
7 days & 0.53 & 0.48 & 0.32 \\
14 days & 0.60 & 0.57 & 0.34 \\
\hline
\end{tabular}

\section{COUMARIN RELEASE OF FABRICATED RMGIC}

Results showed that the coumarin release profile of both RMGIC-AC and RMGIC-CT were not statistically difference $(p>0.05)$. However, the value of coumarin release for RMGIC-CT was slightly higher than RMGIC$\mathrm{AC}$, as showed in Figure 8. This phenomenon may be due to smaller size of CT that enhanced the uniformity of the mixture, thereby controlling the aggregation of the particles (Alyami et al. 2017). In addition, the solubility of CT is predicted to be higher than AC due to its high hydrogen bonding which created more hydrophilicity behavior; and this situation would initiate more release of CT into the tested medium (Hiraishi et al. 2008).

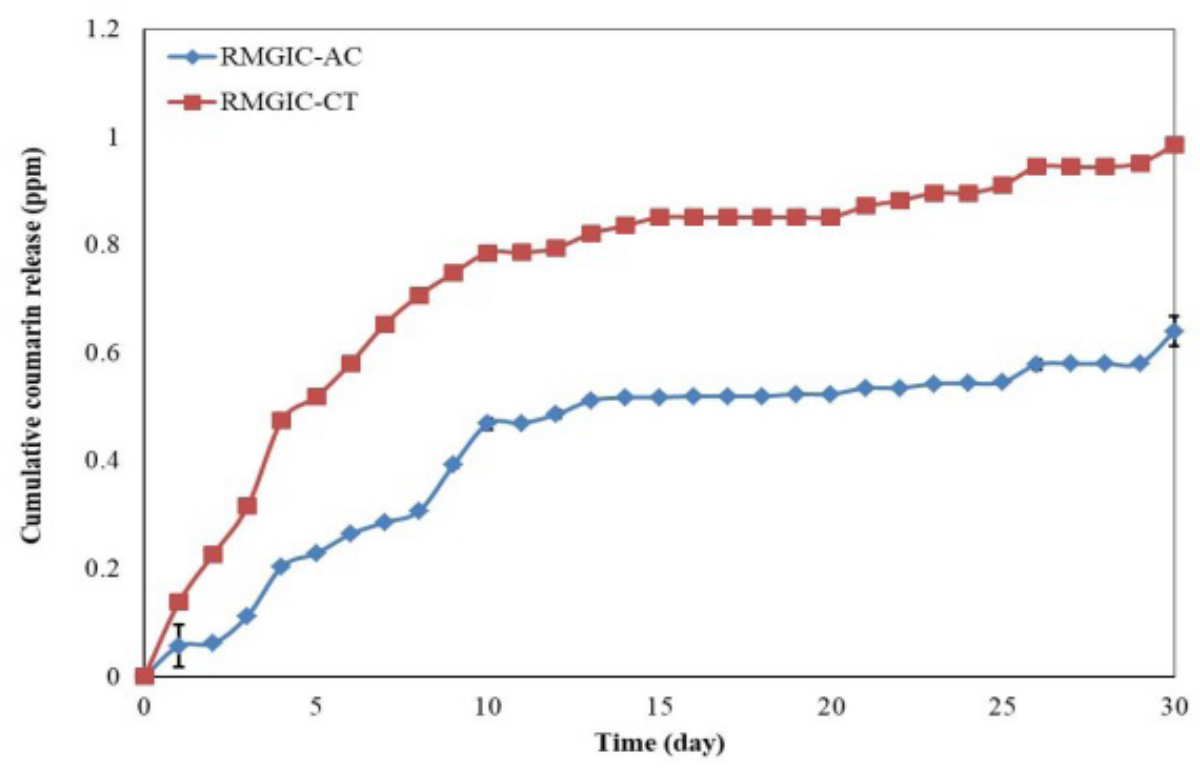

FIGURE 8. Coumarin release profile of RMGIC-AC and RMGIC-CT after 30 days immersion in artificial saliva. The samples are not statistically different according to Mann-Whitney $U$ test; the insignificant value ( $p>$ 0.05 ) between RMGIC-AC and RMGIC-CT 


\section{CONCLUSION}

In conclusion, the effect of large particle size of AC had significantly increased the hardness of fabricated RMGIC. Both fabricated RMGICs had reduced the surface roughness and their coumarin release profile were not significantly difference regardless of different coumarin sizes. Meanwhile, inconsistency of pores formation for RMGIC, RMGIC-AC and RMGIC-CT was observed and the swelling effect on RMGIC's surface was shown at final interval. However, RMGIC-CT has shown the lowest value of pores distribution resulting in a good combination effect. It can be concluded that both RMGIC-AC and RMGIC-CT has different effect in physical properties. Hence, for future study, the evaluation of antibacterial properties for RMGIC-AC and RMGIC-CT against oral microorganisms should be carried out to further confirm the best formulation either RMGIC-AC or RMGIC-CT.

\section{ACKNOWLEDGEMENTS}

This work was supported by Universiti Sains Malaysia Research University Individual Grant (1001/ PPSG/813076). First, the authors would like to thank MyBrain 15 for its financial assistance throughout the study. The authors acknowledge the assistance provided by the staff of the Craniofacial and Biomaterials Laboratory, School of Dental Sciences; School of Health Sciences and Institute for Research in Molecular Medicine (INFORMM), Universiti Sains Malaysia for their testing facilities.

\section{REFERENCES}

Akkus, A., Karasik, D. \& Roperto, R. 2017. Correlation between micro-hardness and mineral content in healthy human enamel. Journal of Clinical and Experimental Dentistry 9(4): e569-e573.

Alomayri, T., Assaedi, H., Shaikh, F.U.A. \& Low, I.M. 2014. Effect of water absorption on the mechanical properties of cotton fabric-reinforced geopolymer composites. Journal of Asian Ceramic Societies 2(3): 223-230.

Alyami, H., Dahmash, E., Bowen, J. \& Mohammed, A.R. 2017. An investigation into the effects of excipient particle size, blending techniques and processing parameters on the homogeneity and content uniformity of a blend containing low-dose model drug. PLOS ONE 129(6): e0178772.

Azlisham, N.A.F., Mahmood, Z. \& Mohamad, D. 2017. Evaluation of surface roughness and compressive strength of modified glass ionomer cement with coumarin derivatives. Journal of Mechanical Engineering 4(2): 216-220.
Azlisham, N.A.F., Rahman, F.S.A. \& Mohamad, D. 2015. Flexural and morphological properties of newly developed glass ionomer cement (GIC) with the incorporation of 3-acetylcoumarin. Malaysian Journal of Microscopy 11(1): 11-15.

Balagopal, S. \& Arjunkumar, R. 2013. Chlorhexidine: The gold standard antiplaque agent. Journal of Pharmaceutical Sciences and Research 5(12): 270-274.

Beltagy, T.M. \& Elhatery, A.A. 2018. Bioactive resin modified GIC vs. conventional one in vivo and in vitro study. Egyptian Dental Journal 64(4): 2917-2931.

Berzins, D.W., Abey, S., Costache, M.C., Wilkie, C.A. \& Roberts, H.W. 2010. Resin-modified glass-ionomer setting reaction competition. Journal of Dental Research 89(1): 82-86.

Chen, L., Suh, B.I. \& Yang, J. 2018. Antibacterial dental restorative materials: A review. American Journal of Dentistry 31(Sp Is B): 6B-12B.

Da Silva, C.M., da Silva, D.L., Modolo, L.V., Alves, R.B., de Resende, M.A., Martins, C.V. \& de Fátima, Â. 2011. Schiff bases: A short review of their antimicrobial activities. Journal of Advanced Research 2(1): 1-8.

Gharechahi, M., Moosavi, H. \& Forghani, M. 2012. Effect of surface roughness and materials composition. Journal of Biomaterials and Nanobiotechnology 3(04): 541-546.

Gilman, J.J. 2009. Chemistry and Physics of Mechanical Hardness. Hoboken, New Jersey: John Wiley \& Sons, Inc.

Hiraishi, N., Yiu, C.K.Y., King, N.M., Tay, F.R. \& Pashley, D.H. 2008. Chlorhexidine release and water sorption characteristics of chlorhexidine-incorporated hydrophobic/ hydrophilic resins. Dental Materials 24(10): 1391-1399.

Hu, Y., Shen, Y., Wu, X., Tu, X. \& Wang, G.X. 2018. Synthesis and biological evaluation of coumarin derivatives containing imidazole skeleton as potential antibacterial agents. European Journal of Medicinal Chemistry 143 958-969.

Kaushik, M., Sharma, R., Reddy, P., Pathak, P., Udameshi, P. \& Vallakuruchi Jayabal, N. 2014. Comparative evaluation of voids present in conventional and capsulated glass ionomer cements using two different conditioners: An in vitro study. International Journal of Biomaterials 2014: 935240.

Kuhn, A.T. \& Wilson, A.D. 1985. The dissolution mechanisms of silicate and glass-ionomer dental cements. Biomaterials 6(6): 378-382.

Kundie, F., Azhari, C.H., Muchtar, A. \& Ahmad, Z.A. 2018. Effects of filler size on the mechanical properties of polymerfilled dental composites: A review of recent developments. Journal of Physical Science 29(1): 141-165.

Mount, G.J., Patel, C. \& Makinson, O.F. 2002. Resin modified glass-ionomers: Strength, cure depth and translucency. Australian Dental Journal 47(4): 339-343.

Najeeb, S., Khurshid, Z., Zafar, M.S., Khan, A.S., Zohaib, S., Martí, J.M.N., Sauro, S., Matinlinna, J.P. \& Rehman, I.U. 
2016. Modifications in glass ionomer cements: Nano-sized fillers and bioactive nanoceramics. International Journal of Molecular Sciences 17(7): 1134.

Nomoto, R., Komoriyama, M., McCabe, J.F. \& Hirano, S. 2004. Effect of mixing method on the porosity of encapsulated glass ionomer cement. Dental Materials 20(10): 972-978.

Özdemir, H. \& Özdoğan, A. 2018. The effect of heat treatments applied to superstructure porcelain on the mechanical properties and microstructure of lithium disilicate glass ceramics. Dental Materials Journal 37(1): 24-32.

Pinto-Sinai, G., Brewster, J. \& Roberts, H. 2018. Linear coefficient of thermal expansion evaluation of glass ionomer and resin-modified glass ionomer restorative materials. Operative Dentistry 43(5): E266-E272.

Puttaraju, K.B., Shivashankar, K., Mahendra, M., Rasal, V.P., Vivek, P.N.V., Rai, K. \& Chanu, M.B. 2013. Microwave assisted synthesis of dihydrobenzo [4,5] imidazo [1, 2-a] pyrimidin-4-ones; synthesis, in vitro antimicrobial and anticancer activities of novel coumarin substituted dihydrobenzo [4, 5] imidazo [1, 2-a] pyrimidin-4-ones. European Journal of Medicinal Chemistry 69: 316-322.

Rahman, F.S.A., Yusufzai, S.K., Osman, H. \& Mohamad, D. 2016. Synthesis, characterisation and cytotoxicity activity of thiazole substitution of coumarin derivatives (Characterisation of coumarin derivatives). Journal of Physical Science 27(1): 77-87.

Rashid, H. 2014. The effect of surface roughness on ceramics used in dentistry: A review of literature. European Journal of Dentistry 8(4): 571-579.

Rohini, K. \& Srikumar, P.S. 2014. Therapeutic role of coumarins and coumarin-related compounds. Journal of Thermodynamics \& Catalysis 5(2): 1-3.

Salem, M.A., Marzouk, M.I. \& El-Kazak, A.M. 2016. Synthesis and characterization of some new coumarins with in vitro antitumor and antioxidant activity and high protective effects against DNA damage. Molecules 21(2): 249.

Sanders, B.J., Gregory, R.L., Moore, K. \& Avery, D.R. 2002. Antibacterial and physical properties of resin modified glass-ionomers combined with chlorhexidine. Journal of Oral Rehabilitation 29(6): 553-558.

Savabi, O., Nejatidanesh, F., Fathi, M.H., Navabi, A.A. \& Savabi, G. 2013. Evaluation of hardness and wear resistance of interim restorative materials. Dental Research Journal 10(2): 184-188.

Sidhu, S.K. 2011. Glass-ionomer cement restorative materials: A sticky subject? Australian Dental Journal 56(Suppl 1): 23-30.

Siegel, R.A. \& Rathbone, M.J. 2012. Overview of controlled release mechanisms. In Fundamentals and Applications of Controlled Release Drug Delivery, edited by Siepmann, J., Siegel, R.A. \& Rathbone, M.J. Switzerland: Springer Science \& Business Media.
Souza, J.C., Silva, J.B., Aladim, A., Carvalho, O., Nascimento, R.M., Silva, F.S., Martinelli, A.E. \& Henriques, B. 2016. Effect of zirconia and alumina fillers on the microstructure and mechanical strength of dental glass ionomer cements. The Open Dentistry Journal 10: 58.

Stefanachi, A., Leonetti, F., Pisani, L., Catto, M. \& Carotti, A. 2018. Coumarin: A natural, privileged and versatile scaffold for bioactive compounds. Molecules 23(2): 250.

Thomas, S., Chan, C.H., Pthen, L.A., Joy, J. \& Maria, H.J. 2014. Natural Rubber Materials - Volume 2: Composites and Nanocomposites. Milton Road, Cambridge: The Royal Society of Chemistry.

Türkün, L.S.E., Türkün, M., Ertuĝrul, F., Ates, M. \& Brugger, S. 2008. Long-term antibacterial effects and physical properties of a chlorhexidine-containing glass ionomer cement. Journal of Esthetic and Restorative Dentistry 20(1): 29-44.

Tüzüner, T. \& Ulusu, T. 2012. Effect of antibacterial agents on the surface hardness of a conventional glass-ionomer cement. Journal of Applied Oral Science 20(1): 45-49.

Venugopala, K.N., Rashmi, V. \& Odhav, B. 2013. Review on natural coumarin lead compounds for their pharmacological activity. BioMed Research International 2013: 1-14.

Yamazaki, Y., Naganuma, J. \& Gotoh, H. 2019. A theoretical, dynamical evaluation method of the steric hindrance in nitroxide radicals using transition states of model reactions. Scientific Reports 9(1): 1-11.

Zafar, M.S. 2014. A comparison of dental restorative materials and mineralized dental tissues for surface nanomechanical properties. Life Science Journal 11(10s): 19-24.

Fatimah Suhaily Abdul Rahman \& Dasmawati Mohamad* School of Dental Sciences, Health Campus

Universiti Sains Malaysia

16150 Kubang Kerian, Kelantan Darul Naim

Malaysia

Habsah Hasan

School of Medical Sciences, Health Campus

Universiti Sains Malaysia

16150 Kubang Kerian, Kelantan Darul Naim

Malaysia

Hasnah Osman

School of Chemical Sciences, Main Campus

Universiti Sains Malaysia

11800 Pulau Pinang

Malaysia

*Corresponding author; email: dasmawati@usm.my

Received: 7 September 2020

Accepted: 7 December 2020 